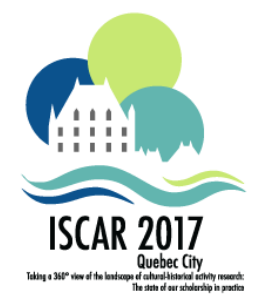

\title{
Elaboration of Cultural-Historical Approach in Developmental and Clinical Psychology: Tendencies and Levels of Analysis
}

\author{
Natalia Burlakova \\ Associate Professor, Neuro- and Patho-Psychology Chair \\ Department of Psychology, the M.V. Lomonosov Moscow State University \\ Moscow, Russia \\ NABURLAKOVA@YANDEX.RU \\ Valery Oleshkevich \\ OV-6161@MAIL.RU \\ Clinical Psychologist of the Highest Category \\ Applied Research Center for Child and Adolescent Mental Health named after G.E. Sukhareva \\ Moscow, Russia
}

\begin{abstract}
The research was focused on the following opportunities of further development of L. S. Vygotsky's cultural-historical approach: 1) further analysis of symbolic mediation methods of mental activity in socially and culturally stratified modern society and 2) cultural-historical analysis use in research of theories and conceptual apparat of clinical psychology. Drawing on performed research, we argue that psychological knowledge should be analyzed in the context of its cultural-historical formation. The application of cultural-historical analysis in different levels provides an opportunity to extend the methodology used for empirical research including research of certain clinical case.

We've developed the integrated cultural-historical approach that combines the ideas of L. S. Vygotsky and M. M. Bakhtin complementing psychology of interiorization with psychology of exteriorization. To develop further, modern cultural-historical psychology needs to extend the "experience" concept and to integrate the experience of depth psychology, inasmuch as an individual develops within the culture, which means, that development is closely related with language and should be analyzed in the context of language and voice dialogues as fundamental conditions of psychological development. Thereby, mental activity is dialogical in its structure - it does not only evolve in dialogue, but is a dialogue at the root as well. Performed research proves L. S. Vygotsky's idea that normal and abnormal development goes in accordance with the same rules. Moreover, normal and abnormal phenomena intertwine in the midst of empirical development of an individual. Historically divergent phenomena provided an opportunity for extension of normal consciousness that places developmental psychology and pathopsychology in the global phenomenological and historical context of analysis.
\end{abstract}

Keywords : L. S. Vygotsky; Symbolic mediation methods of mental activity; Culturalhistorical analysis; Clinical psychology. 
L. S. Vygotsky made a unique contribution in psychology with cultural-historical approach invented by him (Vygotsky, 1978, 1983a, 1983b, 1983c, 1985; Vygotsky \& Luria, 1930). He developed this conception in specific historical conditions that emerged in the 1920s in Russia, when the symbolic activity first began to be considered and analyzed as a significant phenomenon in the development of an individual within the culture. Vygotsky first realized the essential nature of this phenomenon for an individual and began to develop cultural-historical psychology based on interiorization of cultural-historical experience in symbolic form. In the middle of the $20^{\text {th }}$ century, cultural-historical situation in USSR changed, and activity theory based on different methodological approach became a central one in Soviet psychology reflecting this change. The cultural-historical situation in nowadays Russia is different from the one Vygotsky had been developing his ideas in. However, his methodology is fundamental and provides numerous opportunities for further elaboration.

Today, we should work with the methodology of cultural-historical psychology drawing on new cultural conditions that helps to discover new concepts and approaches within this methodology. For instance, it could be used for analysis of different historical as well as modern psychological concepts and practices. If analyzed from the perspective of culturalhistorical approach, every psychological concept reflects social and cultural experience of the society it emerged in. Moreover, cultural-historical experience can be understood as psychotechnical one forming the living psychology of people in this society, therefore reflection of this experience in psychological theory remains psychotechnical as well. If so, it is possible to recognize the psychotechnical scheme the theory is based on (Oleshkevich, $1997,2002,2016)$. It points to the fact that modern psychological concepts are to be analyzed from the cultural-historical perspective. Even more, the Vygotsky's theory needs to be analyzed in such way as well. It emerged in certain cultural and historical conditions, and we are to consider them for deeper comprehension of the theory's structure.

The society in Vygotsky's time was a homogeneous one due to the ambitious historical experiment called Russian revolution. The conception Vygotsky developed was one of the results emerged out of this historical experiment. In recent 20 years, we witness different historical transformations in Russian culture, including rapid development of diverse social groups, heterogeneous cultures and social strata determining different forms of interiorization and even different mechanisms of individual self-awareness development. This situation can be understood as a new historical experiment in Russian society determining new living psychologies people have and therethrough new psychological concepts.

While analyzing modern psychology from the cultural-historical perspective, it is important to distinguish between Russian psychology based on interiorization and Western psychology based on psychoanalysis (Burlakova \& Oleshkevich, 2010; Oleshkevich, 2011). Both methodological approaches actualize cultural-historical situation, but psychology based on interiorization does it explicitly, while psychology based on psychoanalysis derives cultural mechanisms from the self-awareness of an individual actualizing culturalhistorical situation implicitly. However, these two types of psychology complement each other and combining them could be effective, as we have proved in our research integra- 
ting Vygotsky's methodological approach and psychoanalytical concepts (Burlakova, 2016; Burlakova \& Oleshkevich, 2001).

In Russian culture, both methodological approaches existed - M. M. Bakhtin developed the methodology similar to the psychoanalytic approach (Bahtin, 1986; Voloshinov \& Bahtin, 1993). That was psychology of expression, exteriorization, dialog and understanding mental activity as internal "Self - Other" dialogues, and it complemented the Vygotsky's approach. In our research, we have integrated these two approaches making of them solid cultural-historical and dialogical approach aimed at understanding the self-awareness development (Burlakova \& Oleshkevich, 2001). Drawing on this integrated approach, we have described the psychotherapeutic process, built the functionalstructural model demonstrating how the internal dialogues unfold in the mind during the psychotherapeutic session (Burlakova, 1996; Sokolova \& Burlakova, 1997, 2009), depictured internal and external dialogues children lead and characterized their role in the development of child's self-awareness (Burlakova \& Bykova, 2015; Burlakova \& Fedorova, 2016; Burlakova \& Oleshkevich, 2001). This integrated methodological approach reveals new perspectives in the research of diverse cultural-historical phenomena such as, for instance, collective historical memory and its transmission to younger generations or psychodynamic mechanisms of self-awareness used for transmission and transformation of traumatic cultural experience. The capabilities of this approach were shown by analyzing the traumatic experience of Holocaust and the ways of its transmission from survivors to the younger generations (Burlakova, 2016).

As L. S. Vygotsky believed, an objective psychological research is only possible when we examine the development of psychological phenomena, which means that we need to examine the interiorization of external social factors into internal psychological manifestations. This goal appears to be difficult to achieve especially in light of fast-moving modern culture: cultural patterns such as models of upbringing a child come and go quite fast, cultural trends change and intercommunicate. Methodology of interiorization is not enough for examination of such cultural situation. Therefore, we have supplemented the methodology of interiorization with the methodology of exteriorization (including the reflection of its conditions) and with analysis of internal dialogues unfolding in the mind that is necessary for understanding the mechanisms of self-awareness. Such research can be considered as a cultural-historical one, at least because we document and reflect the conditions of data acquisitions (Burlakova, 2011; Burlakova \& Oleshkevich, 2001; Oleshkevich, 2002).

Cultural-historical analysis requires epistemological understanding of psychological concepts and theories as well as their development. Therefore, it is possible to examine psychological theories such as A. Adler's or E. Erikson's theory using cultural-historical approach and to analyze historical conditions when these theories were considered true ones reflecting certain cultural-historical situation (Burlakova \& Fedorova, 2016; Burlakova \& Oleshkevich, 2011, 2012). As our research proves, the theories emerge from certain social groups and are true for these groups, which means that they have cultural-historical conditions of their veracity. 
Scientific theories usually emerge in critical historical periods from problematic or traumatic experience of an individual within the culture. At first, this experience is relevant only for a small social group. Afterwards it spreads to larger segment of society. In such type of research, the cultural-historical analysis helps to understand the cultural conditions of genesis and expansion of the theory examined and to clarify its social, cultural and psychotechnical meaning. The main question to answer is: Why was the personal history of Z. Freud or A. Adler or E. Erikson (and consequently the theories developed by them) relevant for certain social group and in time for the whole society as well? We have tried to traverse this subject in our research (Burlakova, 2012; Burlakova \& Oleshkevich, 2011, 2012; Oleshkevich, 1997). These theories emerge from certain traumatic experience widespread in certain social group that transforms into new psychological norm. In this case, culturalhistorical analysis reveals mechanisms of development of human experience in culture that arises from perception and reflection of certain abnormal and traumatic experience.

Thus, clinical psychology needs a new approach providing cultural-historical analysis both of certain concepts and methodology in general. While performing such an analysis, it is possible to understand how the society generates different types of traumatic phenomena, i.e. to examine how they evolve in culture and to determine their social and cultural place in the society. Such approach presupposes that the whole society could be analyzed as a kind of "clinic" providing certain conditions that provoke certain pathological phenomena.

Therefore, cultural-historical analysis of psychology is to be performed in several levels. First, all the naturalistic researches should be analyzed critically. For instance, statistical research in psychology is in fact naturalistic and atomic. Statistical parameters chosen for research determine obtained results. Moreover, the existing psychiatric classification and culturology of psychiatric clinic - factors that usually remain unanalyzed - determine results (and chosen parameters as well).

The second level of cultural-historical analysis assumes the examination of forms and mechanisms of transformation of external socio-cultural phenomena into internal psychological ones. At this level, the development of culturological and sociological means for description of these processes is of great importance. These means should be properly organized for the goals of psychological research.

The third level of cultural-historical analysis assumes the examination of theoretical and practical methodologies in psychology. Every psychological conception reflects certain cultural-historical situation it emerged from. Therefore, it conceptualizes the experience of its author and certain social group and psychotechnically solves problems relevant for them under the influence of problematic cultural situation. Consequently, it is incorrect to use this theory for solving problems of different social groups without culturological and methodological reflection. However, we can encounter it quite often in modern psychology.

The fourth level of cultural-historical analysis assumes the examination of social institutions, cultural trends etc., i.e. cultural-historical situation modern psychology has been developing in. For instance, in recent years, clinical psychology has been developing within psychiatric clinic (Foucault, 1998, 2010). The psychiatric clinic as a social institution not 
only treats its patients and classifies them into categories, but produces certain type of mental activity and pathology as well. Therefore, clinical psychology receives "square" cultural-historical material for analysis. First, psychological problems emerge in certain cultural-historical situations, and, second, already in psychiatric clinic they are organized in certain way from the perspective of psychiatry. Now there is almost no reflected analysis of such cultural-historical processes. Therefore, the analysis of clinic as a social institution from the cultural-historical perspective appears to be actual for the development of clinical psychology. On the other hand, there is another clinic - clinic of consultative psychological centers, private practicing psychologists and psychotherapists. Already K.G. Jung mentioned that different psychotherapeutic schools had their own type of patients and not only their own methods, but their own system of values as well. This clinic has been waiting for its researchers yet.

Finally, the same scheme could be applied to many institutions - for instance, to the institution of childhood the developmental psychology has been developing in. First, the data gained by Soviet psychology may not correspond with psychological reality today and require reconsideration in new cultural situation. Second, to make the developmental psychology to the cultural-historical discipline it is important to examine social and cultural mechanisms and values strongly influencing and even organizing the child's development.

In fact, cultural-historical psychology always was practice-oriented. On the one hand, it developed as a conceptualization of new soviet culture and society that was being formed at that time. On the other hand, it had been shaping within the sphere of formative experiments and was aimed at cultural-historical analysis of cogitation. That was one of the reasons why L. S. Vygotsky actively started to train blind deaf-mute children. He sought to show that cogitation development and closely connected to it competency in selfadjustment were not directly linked to the development of sensory functions. Cogitation appeared to be connected to the capability of operating with signs. These works of L. S. Vygotsky and his followers made an invaluable contribution to general psychology as well as clinical psychology and correctional pedagogy. The latter developed under the influence of L. S. Vygotsky's formation psychology. Thereafter in USSR, the formation psychology was elaborated practically within the framework of children psychology, pedagogical psychology and clinical psychology. Variety of famous clinical psychologists such as Ivanova (1976); Rubinshtein (1965); Zeigarnik (1958, 1986); Zeigarnik and Bratus (1980), etc. worked in this field (Nikolaeva, 2011; Sokolova, 1976).

Applied neuropsychology and neurorehabilitation with the foundation laid by A.R. Luria is widely known in Russia (Akhutina \& Pylaeva, 2011; Glozman, 2016). As a fact, neurorehabilitation also follows the guidelines of psychology and psychotechnics of formation psychology, which underlies Vygotsky's cultural-historical psychology. The most famous and elaborated approach to formation is the psychology and psychotechnics developed by Gal'perin $(1967,1989,1992)$. He suggests understanding mentality as an orientational activity. Moreover, according to him, this activity can be formed and influenced. Most research conducted within the Galperin's school belongs to the sphere of the pedagogical and children psychology (Podolskiy, 2012; Talysina, 2001). However, this approach appears 
to be perspective in clinical psychology as well. If speaking about the clinical patients, this approach is important particularly for mental spheres with diagnosed deficiency. The approach could be applied to formation of patients' mentality, reorientation, organization of psychocorrection and rehabilitation as well. Further elaboration of P.Ya. Galperin's concept was closely connected to the analysis of importance of problematic situations and of reflection in organization of development, to the psychotechnics of exteriorization etc. (Oleshkevich, 2016; Shhedrovickij, Rozin, Alekseev, \& Nepomnjashhaja, 1968).

We open up new opportunities of applied cultural-historical psychology, when analyzing reflectively and systematically accumulated experience of applied formation psychology as well as analyzing psychotechnically and historically the history of Western psychology, primarily its applied aspects. That offers a possibility to integrate these two fundamental trends of cultural-historical psychology in one solid cultural-historical psychological approach focused primarily on developmental psychology and psychotechnics. In such case, alongside traditional for Soviet psychology concepts of formation and interiorization, we start to use concepts of projection, exteriorization, self-consciousness, inner dialogues etc. within universal psychological paradigm. It means that applied culturalhistorical psychology acquires two perspectives methodologically stipulated by each other: external and internal.

In the sphere of applied inventions, these perspectives appear to be not only a research verification point, but also a supporting point for organization of personal development. Adoption of inner position involving patient's self-consciousness enables to research and to understand phenomenologically structure of her/his inner dialogues, direction of main self-consciousness intentions and to organize from inside and to direct the development and cross correction. However, adoption of external position allows controlling explications of inner world by controlling behavior, activity, objectivization of mentation etc. External perspective affords a possibility of analyzing social and cultural conditions accompanying formation of patient's behavior and of inner structures of self-consciousness. Meanwhile, adoption of these two perspectives offers broader opportunities for application of culturalhistorical psychology in a more systematical way.

From our perspective, cultural-historical psychology ingrates developmental, social, clinical psychology etc., because one cannot understand development without analyzing social relations and without considering a possibility of certain developmental crises, which provide a basis for developmental abnormalities. It represents comprehensive psychology and psychotechnics, analyzes the most important features of mentality, defines and builds the schemes for cultural-historical research of mentality.

We understand intuitively that mentality is shaping within certain society and culture. Nobody raises principal objections against the historical nature of mentality, and corresponding cultural-historical psychology should deal with research of this topic. However, the purpose is not to measure mentality in a naturalistic way, but to understand certain mentality and means of its functioning and development as a structure shaped at certain moment of cultural-historical existence. Methodological elaboration of a such concept in psychology and broader - in humanities - corresponds to the theory of relativity in psy- 
chics, which showed that received data on object of study depend on an observer position - and this theory reversed the situation in physics. A person always exists within history, therefore in a certain fundamental sense she or he represents and expresses historical psychology from the very beginning. Thus, methodological goal consists in finding the ways to perceive and cogitate perspectives of cultural-historical understanding of person's psychology, which means essentially to understand his/her development. In this regard, sequential methodological development of cultural-historical psychology could make a breakthrough in psychology similar to Copernican revolution. Moreover, it concerns the clinical psychology directly.

\section{References}

Akhutina, T. V., \& Pylaeva, N. M. (2011). L. Vygotsky, A. Luria and developmental neuropsychology. Psychology in Russia: State of the art, 4(1), 155-175.

Bahtin, M. M. (1986). Jestetika slovesnogo tvorchestva [The aesthetics of verbal art]. Iskusstvo, Moscow [in Russian].

Burlakova, N. S. (1996). Internal dialogue in the structure of self-awareness and its dynamic in the process of psychotherapy. Ph.D. Dissertation. Lomonosov Moscow State University, Faculty of Psychology [in Russian].

Burlakova, N. S. (2011). On new opportunities and prospects of development of projective study. Psychology in Russia: State of the art, 4(1), 243-260.

Burlakova, N. S. (2012). New perspectives of cultural-historical analysis in clinical psychology. Moscow University Psychology Bulletin. Series 14. Psychology, 2, 49-56.

Burlakova, N. S. (2016). Psychodynamics of intergenerational trauma experience transmission in the context of cultural-historical clinical psychology. Psikhologicheskie Issledovaniya [Psychological Research], 9(45), 11. http://psystudy.ru/index.php/eng/ 2016v9n45e/1253-burlakova45e.html.

Burlakova, N. S., \& Bykova, P. S. (2015). "Fairytale pedagogy" and non-fairy risks in emotional and personal development of the preschool children. National psychological journal, 2(18), 123-133. doi: 10.11621/npj.2015.0213

Burlakova, N. S., \& Fedorova, Y. N. (2016). Example of practice-oriented research based on case formulation method. Konsul'tationaia psikhologiia i psikhoterapiia [Counseling Psychology and Psychotherapy], 24(1), 109-129. doi: 10.17759/cpp.2016240108

Burlakova, N. S., \& Oleshkevich, V. I. (2001). Projective techniques: theory, practical application to the investigation of the child's personality. Moscow.

Burlakova, N. S., \& Oleshkevich, V. I. (2010). Development of psychotherapy as an object of holistic understanding and systemic research. Kul'turno-istoricheskaya psikhologiya [Cultural-Historical Psychology].(2), 88-97.

Burlakova, N. S., \& Oleshkevich, V. I. (2011). Psychological conception of identity developed by E. Erikson from the perspective of E. Erikson's personal history. Moscow.

Burlakova, N. S., \& Oleshkevich, V. I. (2012). Levels of cultural historical analysis in clinical psychology. Voprosy psikhologii.(6), 35-44.

Foucault, M. (1998). Rozhdenie kliniki [The birth of the clinic]. Moscow: Smysl.

Foucault, M. (2010). Istorija bezumija v klassicheskuju jepohu [Madness and insanity: History of 
madness in the classical age]. Moscow: AST.

Gal'perin, P. Y. (1967). On the notion of internalization. Soviet Psychology, 5(3), 28-33.

Gal'perin, P. Y. (1989). Organization of mental activity and the effectiveness of learning. Soviet Psychology, 27(3), 65-82.

Gal'perin, P. Y. (1992). Stage-by-stage formation as a method of psychological investigation. Journal of Russian and East European Psychology, 30(4), 60-80. doi: 10.2753/RPO1061 $-0405300460$

Glozman, J. M. (2016). Vygotsky in applied neuropsychology. Psychology in Russia: State of the Art, 9(4), 73-79.

Ivanova, A. (1976). Obuchaushij eksperiment kak metod ocenki umstvennogo razvitiya detej (metodicheskie rekomendacii) [Teaching experiment as a method of assessing cognitive development (guidelines)]. Moscow.

Nikolaeva, V. V. (2011). B. V. Zeigarnik and pathopsychology. Psychology in Russia: State of the Art, 4(1), 176-192.

Oleshkevich, V. I. (1997). Genesis of new psychotechnical culture. Moscow.

Oleshkevich, V. I. (2002). History of psychotechnics. Moscow.

Oleshkevich, V. I. (2011). Cultural-historical analysis in the western "psychotheraputic" psychology and new forms of cultural-historical psychology. Cultural-Historical Psychology.(1), 99-107.

Oleshkevich, V. I. (2016). Psychology as psychotechnics. Moscow.

Podolskiy, A. (2012). Development and learning. In N. Seel (Ed.), International encyclopedia on of sciences of learning (pp. 944-950). New York: Springer.

Rubinshtein, S. Y. (1965). Ispol'zovanie jeksperimental'nogo metoda dlya izucheniya psikhopatologicheskih yavlenij [Using an experimental method to study psychopathological phenomena]. In Voprosy e'ksperimental'noj patopsikhologii [issues of experimental pathopsychology]. Moscow.

Shhedrovickij, G. P., Rozin, V. M., Alekseev, N. G., \& Nepomnjashhaja, N. (1968). Pedagogika i logika [Pedagogics and logic]. Moscow (in Russian).

Sokolova, E. T. (1976). Motivaciya i vospriyatie v norme i patologii [motivation and perception in health and disease]. Moscow: Izd-vo Mosk. un-ta.

Sokolova, E. T., \& Burlakova, N. S. (1997). On grounds of case dialogue analysis. Voprosy Psikhologii.(2), 61-76.

Sokolova, E. T., \& Burlakova, N. S. (2009). Reconstruction of inner dialogue in the psychotherapeutic process (a case study). In Y. Zinchenko \& V. Petrenko (Eds.), Psychology in russia state of the art. scientific yearbook. (Vol. 2, p. 413-440). Moscow: Russian Psychological Society.

Talysina, N. F. (2001). Die tätigkeitstheorie des lernens als grundlage einer neuen didaktik. Jeder Mensch kann lernen-Perspektiven einer kulturhistorischen (Behinderten-) Pädagogik, $S, 204-221$.

Voloshinov, V. N., \& Bahtin, M. M. (1993). Marksizm i filosofiya yazyka: Osnovnye problemy sociologicheskogo metoda $v$ nauke o yazyke. Moscow: Labirint.

Vygotsky, L. S. (1978). Mind in society: The development of higher psychological processes. Cambridge: Harvard University press.

Vygotsky, L. S. (1983a). Diagnostika razvitiya i pedologicheskaya klinika trudnogo detstva [developmental diagnostics in a pedological clinic]. In L.vygotsky, collected works 
(Vol. 5). Moscow: Prosveschenie.

Vygotsky, L. S. (1983b). Istorija razvitija vpf [history of development of hmf]. In L.vygotsky, collected works (Vol. 3). Moscow: Prosveschenie.

Vygotsky, L. S. (1983c). O psykhologicheskih systemakh. [on psychological systems]. In L. s. vygotsky collected papers (Vol. 1, p. 109-132). Moscow: Pedagogika.

Vygotsky, L. S. (1985). Defekt i kompensaciya [defect and compensation]. In L.vygotsky, collected works (Vol. 5). Moscow: Prosveschenie.

Vygotsky, L. S., \& Luria, A. R. (1930). Etudy po istorii povedeniya [studies on the history of behavior]. Moscow: Gosizdat.

Zeigarnik, B. V. (1958). Narusheniya myshleniya u psikhicheski bol'nyh [disturbances of thinking in psychiatric patients]. Moscow: Gos. NII psikhiatrii.

Zeigarnik, B. V. (1986). Patopsikhologiya [pathopsychology]. Moscow: Izd-vo Mosk. un-ta.

Zeigarnik, B. V., \& Bratus, B. S. (1980). Ocherki po psikhologii anomal'nogo razvitiya lichnosti [essays in the psychology of abnormal personality development]. Moscow: Izd-vo Moskovskogo un-ta. 